\title{
The influence of the area of the Serra da Mesa Hydroelectric Plant, State of Goiás, on the frequency and diversity of anophelines (Diptera: Culicidae): a study on the effect of a reservoir
}

\author{
Vanessa Melandri ${ }^{[1]}$, Jerônimo Alencar ${ }^{[1]}$ and Anthony Érico Guimarães ${ }^{[1]}$
}

[1]. Laboratório de Diptera, Fundação Oswaldo Cruz, Instituto Oswaldo Cruz, Ministério da Saúde, Rio de Janeiro, RJ.

\begin{abstract}
Introduction: Bioecological aspects of anophelines (Diptera: Culicidae) near areas under the direct influence of the hydroelectric plant reservoir of Serra da Mesa in Goiás, Brazil, were analyzed. Methods: Samples were collected at the surrounding dam area during the phases before and after reservoir impoundment. The influence of climatic and environmental factors on the occurrence of Anopheles darlingi, Anopheles albitarsis, Anopheles triannulatus, Anopheles oswaldoi and Anopheles evansae was assessed using Pearson's correlations with indicators for richness and diversity as well as the index of species abundance (ISA) and the standardized index of species abundance (SISA). Results: The highest anopheline density occurred during the phase after filling the tank; however, no direct correlation with the climatic factors was observed during this stage. The reservoir formation determined the incidence of the anopheline species. An. darlingi was the predominant species (SISA = 1.00). Conclusions: The significant difference $(\mathrm{p}<0.05)$ observed between the species incidence during the different reservoir phases demonstrates the environmental effect of the reservoir on anophelines.
\end{abstract}

Keywords: Anophelines. Hydroelectric plants. Environmental impact.

\section{INTRODUCTION}

With its especially diverse geographical setting of extensive forest regions and favorable rainfall patterns, Brazil is among the countries with the greatest renewable energy potential in the world. Currently, approximately $80 \%$ of all of the energy produced in Brazil is based on an electrical system fueled primarily by hydroelectric plants.

Despite generating energy from a naturally renewable source and being considered clean energy given that it does not contaminate or release toxic substances into nature, hydroelectric power plants have significant effects on the environment. These plants have been associated with the emergence and increase of various pathogens that are transmitted by mosquito vectors that infect humans and wild animals.

Essentially, the power generated by hydroelectric plants originates from the damming of rivers and the formation of large water reservoirs. These constructions cause environmental and

Address to: Dr. Anthony Érico Guimarães. Laboratório de Diptera/FIOCRUZ. Av. Brasil 4365, Manguinhos, 21040-360 Rio de Janeiro, RJ, Brasil.

Phone: 5521 2562-1472

e-mail: anthony@ioc.fiocruz.br

Received 3 December 2014

Accepted 10 February 2015 social effects related to the removal of riverine populations and the changes in the flow of the dammed river. These alterations interfere with the biological and social systems of the affected regions and, in some cases, can lead to the emergence or increase of disease ${ }^{(1)}$.

The Serra da Mesa hydroelectric Power Plant [Usina Hidrelétrica de Serra da Mesa (UHSM)] and its associated reservoir is the largest in Brazil in terms of water volume, with 54.4 billion cubic meters; it is associated with a flooded area of $1,784 \mathrm{~km}^{2}$. The importance and extent of its construction resulted in a large influx of humans to the region, the emergence of new urban centers and significant wood and gold extraction. These actions resulted in the deforestation of large areas, not including to those already affected by the reservoir impoundment. In its entirety, the UHSM powers five major cities in Goiás: Minaçu, Campinorte, Uruaçu, Barro Alto and Niquelândia. Furthermore, this power plant has caused profound changes in the local natural habitat.

Studies of similar developments ${ }^{(1)}$ (2) (3) (4) (5) (6) have demonstrated a strong association between environmental changes (e.g., the formation of hydroelectric reservoirs) and the emergence of malaria (via the increased incidence of anopheline mosquitoes). Guimarães ${ }^{(7)}$ observed that environmental changes lead to changes in the degree of the incidence of malaria in regions endemic for this disease.

Thus, the present study evaluated the changes in the diversity and density of anopheline populations in the localities directly affected by the reservoir formation of the UHSM. 


\section{METHODS}

As described in detail by Guimarães ${ }^{(7)}$, anophelines were captured in the five municipalities under the direct influence of the UHSM reservoir, namely Minaçu, Campinorte, Uruaçu, Barro Alto and Niquelândia. The samples were collected every two months for five consecutive days at each sampling point over the three-year study period, which was composed of three impoundment phases. Phase I corresponded to the period prior to the start of the reservoir filling; these samples were considered as the control and standard for the incidence of anophelines in the region. Phase II corresponded to the period between the beginning of the filling of the reservoir until the beginning of plant operation. Finally, Phase III corresponded to the period after the start of plant operation.

\section{Study area}

To assess the effect of the reservoir in each municipality, five sampling points with different environmental settings were established. These settings ranged from the UHSM construction site to zones of new human population, mining camps and areas of mineral exploitation.

Area 1: the Municipality of Minaçu. This sampling point was located at the UHSM construction site between S13 ${ }^{\circ} 49^{\prime} 26.9^{\prime \prime}$ and W $48^{\circ} 18^{\prime} 56.5^{\prime \prime}$ on the east bank of the Tocantins River near the secondary dam (i.e., Dyke II), $5 \mathrm{~km}$ from the major reservoir dam. The forest in this area is dense, with strong characteristics of cerrado or dense woodlands, trees of approximately $6 \mathrm{~m}$ in height and canopies that occlude light penetration to the lower strata. These canopies enable the occurrence of a thicker layer of organic matter. The forest reaches the banks of the reservoir, forming shaded backwaters.

Area 2: the Municipality of Campinorte. This sampling point was located at S $14^{\circ} 05^{\prime} 38.5^{\prime \prime}$ and W $48^{\circ} 59^{\prime} 51.3^{\prime \prime}$ on the west bank of the Tocantins River in the areas of Planeta Água Farm, $18 \mathrm{~km}$ from the secondary access in Jerusalem on highway BR-153. These samples were performed at the edge of a spring of a creek that flowed into the reservoir, where we observed fertile soils and vegetation typical of gallery forests that formed dense, predominantly arboreal vegetation. The humidity and water availability maintained the vegetation throughout the year, thereby providing an ecotope that did not suffer because of the drought period.

Area 3: the Municipality of Uruaçu. This sampling point was located at S $14^{\circ} 32^{\prime} 04.4^{\prime \prime}$ and $\mathrm{W} 49^{\circ} 01^{\prime} 07.8^{\prime \prime}$ on the east bank under the bridge of the Tocantins River, $14 \mathrm{~km}$ from the entry point of the Uruaçu municipality near highway GO-237. The influx of people to this region was large, and many commercial fishing and leisure activities are associated with this reservoir. The vegetation includes shrubbery with a few trees above $3 \mathrm{~m}$ in height. The understory consists of small shrubs and a soil covered by sparse patches of leaf litter. Because the vegetation does not directly reach the banks of the reservoir, extensive areas with clear signs of deforestation can be observed. During the dry season, the few shaded backwaters are exposed to sunlight, and the banks of the reservoir become arid.
Area 4: the Municipality of Barro Alto. This sampling point was located at S $14^{\circ} 39^{\prime} 47.9^{\prime \prime}$ and W $48^{\circ} 57^{\prime} 35.2^{\prime \prime}$ on the west bank of the Tocantins River amid areas of gold mining, $27 \mathrm{~km}$ from the secondary access of the district of Placa and highway BR-080. This entire area has been severely altered because of gold mining activity. The humans in this region reside in poor living conditions such as huts without basic personal sanitation, the disposal of appliances and food, or both. The active transit of trucks needed to transport people, equipment and mining material heavily altered this geographic setting throughout the anopheline sampling. It remains possible to find woods near the mining areas with typical cerrado characteristics such as spaced trees and dominant shrubbery. The soil is low in organic matter, often sandy and exposed to sunlight. The Tocantins River forms at the site of the tranquil backwaters where the sparse vegetation maintains shaded banks.

Area 5: the Municipality of Niquelândia. This sampling point was located at S $14^{\circ} 26^{\prime} 51.0^{\prime \prime}$ 'and W $48^{\circ} 57^{\prime} 34.6^{\prime \prime}$ on the east bank of the Tocantins River in the area of Córrego Dantas Farm, $9 \mathrm{~km}$ away from the secondary access of Vendinha on highway GO-237. Despite being the region most heavily affected by the UHSM reservoir, it remains possible to find patches of land with characteristics of the original cerrado, although without the cerrado formations present in the other localities. The entire region is located between the county centers of Uruaçu and Niquelândia, and it is formed by the large soybean farms as well as livestock breeding and settlement areas of small subsistence farming colonies. The human presence in this area is striking: Humans live in simple houses near the reservoir, with an everyday life closely linked to fishing. The vegetation is altered because of the deforestation due to agriculture and livestock. Nevertheless, it is possible to find more dense shrubs clusters and soil covered by grass next to the reservoir.

\section{Data analysis}

The index of species abundance (ISA) and the standardized index of species abundance (SISA) were used to analyze the data obtained from the collections based on the definitions of Robert and $\mathrm{Hsi}^{(8)}$. The ISA was calculated using the following formula:

$$
\mathrm{ISA}=\frac{(a \pm R j)}{k}
$$

Where $k$ is the number of collections, $a$ is the number of species not present in $k$ multiplied by $\mathrm{c}$, $\mathrm{c}$ is the highest position of the species in $k$ plus 1 , and $R j$ is the sum of the classifications of each species.

To standardize this index, it was converted to a scale between 0 and 1 using the SISA calculation: SISA $=\frac{(c-I S A)}{(c-I)}$

$$
(\mathrm{c}-1)
$$

A species was considered as the most abundant when the SISA was closest to its maximum of 1 . The results provide information regarding the relative abundance of the species and the spatial distribution of the collected individual samples.

The relationship between the phases of the reservoir filling and the presence of anophelines was determined using the paired 
t-test analysis (SYSTAT 8.0) between the species abundance of each phase. To establish an average, the values of each phase were converted to the Williams mean (Xw) as defined by Haddow ${ }^{(9)}$. To define the association between the collected anophelines and the climate data, Pearson's correlation analysis was used. The number of samples collected during each phase of the reservoir was used to establish the critical value of $r$. The climate data were obtained from the National Weather Service [Instituto Nacional de Meteolorogia (INMET)].

The species diversity analysis for the study area was assessed using the Shannon-Wiener Diversity Index $(\mathrm{H})$ and the Evenness Index $(\mathrm{EH})$, which describe the parameters characteristic of the region. The H' evaluates diversity to compare communities with regard to biodiversity conservation and management to assess the effects of human disturbance and make environmental policy decisions. The EH' assesses how the species are distributed in a homogeneous manner based on the number of specimens collected during each period. The diversity indices were established during each reservoir stage using Past ${ }^{(10)}$.

\section{RESULTS}

A total of 5,395 anophelines were captured in the samples collected from the five municipalities near the UHSM reservoir.
These anophelines belonged to the species Anopheles darlingi, Anopheles albitarsis, Anopheles triannulatus, Anopheles oswaldoi and Anopheles evansae.

The abundance index analysis revealed that An. darlingi was the predominant species $(\mathrm{SISA}=1.00)$ for all of the reservoir phases. The remaining species listed in Table 1 maintained the same order of dominance, regardless of the filling period. The incidence calculations according to $\mathrm{Xw}$ showed that the most frequent species was $A n$. darlingi, which presented the highest $\mathrm{Xw}$ frequency values during Phase I (50.3\%), Phase II (56.3\%) and Phase III (59.9\%), followed by An. albitarsis, An. triannulatus, An. oswaldoi and An. evansae (Table 2).

However, the anopheline incidence analyses for each of the three studied reservoir phases revealed that Phase II (which began when the reservoir was filled to capacity) had the highest incidence of anophelines, with an Xw value of 518.7. This value represented an increase of nearly 15 times the total incidence of anophelines during Phase I $(\mathrm{Xw}=35)$. This value corresponds to the control phase of the study because it does not reflect the influence of the reservoir. A decrease in the incidence of anophelines was observed during Phase III $\left(X_{\mathrm{w}}=37.2\right)$, which approached the value of the control phase (Table 2). The comparative analysis of the abundance index indicated a significant difference $(p<0.05)$ among the phases of the reservoir, confirming its effect on anophelines (Table 3 ).

TABLE 1 - The abundance index converted to the SISA for anophelines captured at the UHSM in Goiás.

\begin{tabular}{|c|c|c|c|c|c|c|}
\hline & \multicolumn{3}{|c|}{ ISA } & \multicolumn{3}{|c|}{ SISA } \\
\hline Anopheles darlingi & 1 & 1 & 1 & 1.00 & 1.00 & 1.00 \\
\hline Anopheles albitarsis & 2 & 2 & 2.3 & 0.50 & 0.50 & 0.33 \\
\hline Anopheles triannulatus & 3 & 3 & 3.8 & 0.33 & 0.33 & 0.07 \\
\hline Anopheles evansae & - & 6 & - & - & 0.00 & - \\
\hline
\end{tabular}

UHSM :Usina Hidrelétrica de Serra da Mesa; ISA: index of species abundance; SISA: standardized index of species abundance.

TABLE 2 - The number and Xw values for the anophelines captured over the three reservoir phases of the UHSM in Goiás.

\begin{tabular}{|c|c|c|c|c|c|c|c|c|c|}
\hline Species & \multicolumn{3}{|c|}{ Phase I } & \multicolumn{3}{|c|}{ Phase II } & \multicolumn{3}{|c|}{ Phase III } \\
\hline An. darling & 58 & 17.60 & 50.3 & 2,696 & 292.00 & 56.3 & 552 & 22.30 & 59.9 \\
\hline An. albitarsis & 52 & 15.43 & 44.0 & 1,516 & 212.37 & 40.9 & 346 & 13.45 & 36.1 \\
\hline An. triannulatus & 6 & 2.00 & 5.7 & 100 & 10.88 & 2.1 & 34 & 1.23 & 3.3 \\
\hline An. evansae & 0 & 0.00 & 0.0 & 11 & 1.31 & 0.3 & 0 & 0.00 & 0.0 \\
\hline Total & 116 & 35.03 & 100.0 & 4,343 & 518.70 & 100.0 & 936 & 37.24 & 100.0 \\
\hline
\end{tabular}

UHSM :Usina Hidrelétrica de Serra da Mesa; N: number; $\mathbf{X}_{\mathbf{w}}$ : values of Anopheles. Phase I: before the reservoir formation; Phase II: during the reservoir formation; Phase III: plant operation. An.: Anopheles. 
TABLE 3 - The species frequency, compared using paired $t$-tests, before and after the reservoir of the UHSM in Goiás.

\begin{tabular}{|c|c|c|c|c|c|}
\hline \multirow[b]{2}{*}{ Species } & \multicolumn{2}{|c|}{ Phase I } & \multicolumn{2}{|c|}{ Phase II } & \multirow[b]{2}{*}{ p-value } \\
\hline & $\mathrm{X}$ & $95 \%$ CIs & $\mathrm{X}$ & $95 \%$ CIs & \\
\hline An. darlingi & 3.87 & 1.45 to 6.29 & 88.52 & 60.06 to 116.97 & 0.0001 \\
\hline An. albitarsis & 3.47 & 0.42 to 6.51 & 49.77 & 31.05 to 68.50 & 0.0006 \\
\hline An. triannulatus & 0.40 & -0.05 to 0.86 & 3.23 & 1.66 to 5.57 & 0.0075 \\
\hline
\end{tabular}

UHSM: Usina Hidrelétrica de Serra da Mesa; X: absolute average; An.: Anopheles.

The fluctuation in the abundance of anophelines was directly related to the climatic factors of the absent reservoir during Phase I. During this phase, increases in air humidity, temperature and, principally, the pluviometric indices were associated with the increased number of specimens collected. During the formation of the reservoir (Phase II), a weak correlation with abundance was observed, especially with regard to the pluviometric indices that presented a nearly non-existent correlation. However, the rain returned to influence Phase III, showing a strong correlation with anopheline abundance (Table 4).

The H' analysis did not reveal significant differences between the anopheline collections performed over the three reservoir phases $\left(\mathrm{H}^{\prime}=0.86, \mathrm{H}^{\prime}=0.79\right.$ and $\left.\mathrm{H}^{\prime}=0.82\right)$. Thus, despite the increase in the incidence of anophelines from $\mathrm{Xw}=35$ to $\mathrm{Xw}=518.7$, which was directly related to the reservoir filling, the diversity index of this genus remained unchanged in the presence of the reservoir. However, the equitability index showed a small decrease during the second phase $\left(\mathrm{E}^{\prime} \mathrm{H}=0.44\right)$ compared with the control phase $\left(E^{\prime} H=0.79\right)$. Although Phase II showed the greatest species richness ( 5 species $)$ and incidence $(\mathrm{Xw}=518.7)$, it also showed a lower homogeneity in the distribution of the individuals among the species (Table 5). This result reflects the strong dominance of An. darlingi, which represented over $50 \%$ of all specimens captured, thereby influencing the homogeneity of the distribution.

\section{DISCUSSION}

Invariably, the natural habitat near hydroelectric project areas is seriously altered with the formation of the water reservoir that is responsible for power generation. Studies of the population densities of anophelines throughout the process of filling reservoirs have established the variables involved in the interaction of these mosquitoes and their new environmental structure. The adaptive dynamic of anophelines has been observed since the first changes caused by the deforestation in this area and the initiation of the reservoir formation.

We found that the abundance index was determined by the quantity of the specimens and the manner in which they were distributed throughout the samples. The effect of the reservoir did not influence the species dominance (i.e., all species were proportionally affected). Paula ${ }^{(11)}$ reported similar results regarding the dominance of mosquitoes in hydroelectric project areas.

In the samples collected before the start of the reservoir formation during Phase I, the population of An. darlingi showed a low frequency of approximately $1.8 \%$ of the total species collected throughout the study $(n=3,306)$, in contrast to the $81.5 \%$ observed during Phase II when the reservoir was filled

TABLE 4 - The linear correlation coefficient (r) between the abundance of anophelines collected over the three filling phases of the UHSM in Goiás by temperature $\left({ }^{\circ} \mathrm{C}\right)$, relative humidity $(\%)$ and precipitation $(\mathrm{mm})$.

\begin{tabular}{|c|c|c|c|c|c|c|c|c|c|}
\hline \multirow{2}{*}{$\begin{array}{l}\text { Reservoir phase } \\
\text { Species }\end{array}$} & \multicolumn{3}{|c|}{$\begin{array}{c}\text { Phase I } \\
r_{0,05(2) 15}=0.52\end{array}$} & \multicolumn{3}{|c|}{$\begin{array}{c}\text { Phase II } \\
r_{0,05(2) 30}=0.38\end{array}$} & \multicolumn{3}{|c|}{$\begin{array}{c}\text { Phase III } \\
r_{0,05(2) 45}=0.29\end{array}$} \\
\hline & $\mathrm{mm}$ & ${ }^{\circ} \mathrm{C}$ & $\%$ & $\mathrm{~mm}$ & ${ }^{\circ} \mathrm{C}$ & $\%$ & $\mathrm{~mm}$ & ${ }^{\circ} \mathrm{C}$ & $\%$ \\
\hline An. darling & 0.92 & 0.65 & 0.27 & 0.04 & 0.57 & 0.29 & 0.74 & 0.05 & 0.45 \\
\hline An. albitarsis & 0.97 & 0.66 & 0.59 & 0.04 & 0.39 & 0.35 & 0.67 & 0.02 & 0.42 \\
\hline An. oswaldoi & - & - & - & 0.32 & 0.68 & 0.34 & 0.79 & 0.14 & 0.28 \\
\hline An. evansae & - & - & - & 0.04 & 0.73 & 0.52 & - & - & - \\
\hline Total & 0.94 & 0.53 & 0.59 & 0.04 & 0.51 & 0.31 & 0.72 & 0.04 & 0.44 \\
\hline
\end{tabular}

UHSM: Usina Hidrelétrica de Serra da Mesa; An.: Anophales. 
TABLE 5 - The diversity index over the reservoir phases of the UHSM in Goiás.

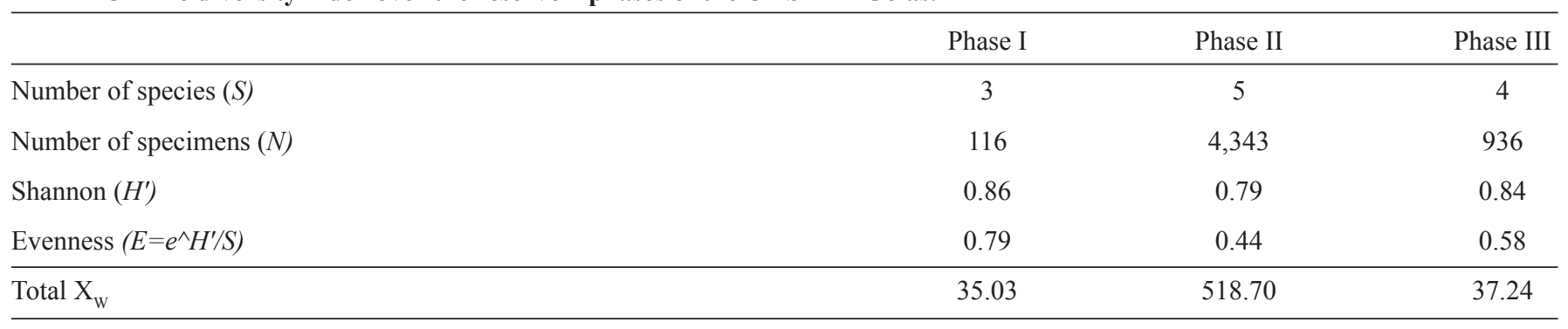

UHSM: Usina Hidrelétrica de Serra da Mesa; $\mathbf{X}_{\mathrm{w}}$ : values of Anopheles.

to its maximum capacity. These figures clearly demonstrate the great capacity for adaption within this species and how the effects of waterlogging favorably influenced the occurrence of An. darlingi in an area where a large hydroelectric project was installed. Because An. darlingi is the primary malaria vector in Brazil $^{(12)}$, its direct relationship with reservoir formation requires continuous monitoring; moreover, the risk of disease occurrence in these areas should be constantly reassessed ${ }^{(7)}$.

Studies conducted near the Itaipu Hydroelectric Plant ${ }^{(1)}$ demonstrated that reservoir formation was responsible for the favorable breeding conditions of An. darlingi and An. albitarsis. These authors have reported the occurrence of thousands of new cases of malaria in locations where this disease was thought to be eradicated approximately 30 years ago due to the reintroduction of anophelines and the migration of workers from other areas of Brazil with high rates of malaria. Importantly, however, the present study (unlike Guimarães ${ }^{(1)}$ ) did not find that these anophelines had a constant population density throughout the year. In the case of the UHSM during Phase III (i.e., immediately after the start of the plant operation), we found a significant reduction in the incidence of anophelines. This finding might be related to two concurrent events: the low rainfall across almost all of Brazil caused by El Nino and the resulting need for the UHSM to function at full power generation capacity to compensate for the energy deficiencies at other hydroelectric plants most affected by the prolonged drought. The combination of these events led to a significant decrease in the volume of water in the tank, reaching the maximum negative index of 12 meters and exposing the banks of the reservoir to direct sunlight. This event prevented the posture and development of immature forms of anophelines and drastically reduced the incidence of these species. This reduction in the anopheline population consequently reduced the incidence of malaria in a manner proportional to the abundance of anophelines ${ }^{(7)}$.

During the first stage of the studies that occurred before filling the reservoir in Phase I, we observed a significant relationship between the occurrence of anophelines and particular regional climate characteristics. Similar studies ${ }^{(13)(14)}$ have reported that rainfall primarily controls the availability of breeding sites and the abundance of mosquitoes. However, the early formation of the reservoir during Phase II resulted in the flooding of vast areas of forest and the presence of decaying vegetation around the reservoir, which significantly favored An. darling because this species preferentially uses these environments for egg laying and the breeding of its larvae. This result demonstrates that climatic factors had a secondary influence on the result of this study ${ }^{(6)(7)(15)(16)}$. An. darlingi was the most frequent anopheline, and its high incidence, the reservoir stability and the arrival of miners were responsible for the malaria cases diagnosed in the region ${ }^{(7)}$.

The Shannon-Wiener Diversity Index did not show significant differences between the collections performed across the three reservoir phases, which indicates that the diversity index remained constant, regardless of the level of the reservoir, despite the significant increase in the incidence of anophelines directly related to the reservoir filling. A similar phenomenon was observed for An. darlingi in other areas influenced by the hydroelectric projects on the border of São Paulo and Mato Grosso do Sul during the periods before and after the reservoir formation ${ }^{(6)}$.

The equitability index showed a small decrease during Phase II compared with Phase I. Thus, although species richness and species incidence were highest during Phase II, it was also the least homogeneous with regard to the distribution of individuals. This reduction was because of the high percentage of An. darlingi and An. albitarsis specimens collected (97\%). The other three species composed the remaining $3 \%$, causing the equitability index to be lower during this period.

\section{CONFLICT OF INTEREST}

The authors declare that there is no conflict of interest.

\section{FINANCIAL SUPPORT}

Furnas Centrais Elétricas. Vanessa Melandre is a scholarship of Coordenação de Aperfeiçoamento de Pessoal de Nivel Superior (CAPES) in the Doctor of Biodiversity and Health Program at Fundação Oswaldo Cruz (FIOCRUZ). Instituto Oswaldo Cruz (IOC), Ministério da Saúde (MS), Rio de Janeiro, RJ, Brazil.

\section{REFERENCES}

1. Guimarães AE, Mello RP, Lopes CM, Alencar J, Gentile C. Prevalência de anofelinos (Diptera: Culicidae) no crepúsculo vespertino em áreas da usina hidrelétrica de Itaipu, no município 
de Guairá, Estado do Paraná, Brasil. Mem Inst Oswaldo Cruz 1997; 92:745-754

2. Tadei WP, Santos JMM, Costa WLS, Scarpassa VM. Biologia de anofelinos amazônicos. XVII. Ocorrência de espécies de Anopheles, dinâmica da transmissão e controle da malária na zona urbana de Ariquemes (Rondônia). Rev Inst Med Trop Sao Paulo 1988; 30 : 221-251.

3. Lourenço-de-Oliveirra R, Guimarães AEG, Arlé M, Silva TF, Castro MG, Motta MA, et al. Anopheline species, some of their habits and relation to malaria in endemic areas of Rondônia State, Amazon Region of Brazil. Mem Inst Oswaldo Cruz 1989; 84:501-514.

4. Marques AC, Cardenas H. Combate a malária no Brasil: evolução, situação atual e perspectivas. Rev Soc Bras Med Trop 1994; 27:91108.

5. Quintero LO, Thatcher BD, Tadei P. Biologia de anofelinos amazônicos. XXI. Ocorrência de espécies de Anopheles e outros culicídeos na área de influência da Hidrelétrica de Balbina cinco anos após o enchimento do reservatório. Acta Amazônica 1996; 26:281-296.

6. Gomes AC, Paula MB, Natal D, Gotlieb SLD. Ecologia de Anopheles (Nyssorhynchus) darlingi Root em área de implantação de empreendimento hidrelétrico, na divisa dos Estados do Mato Grosso do Sul e São Paulo. Rev Soc Bras Med Trop 2010; 43:272-276.

7. Guimarães AE, Gentile C, Alencar J, Lopes CM, Mello RP. Ecology of Anophelinae (Diptera: Culicidae) vectors of malaria in area of Serra da Mesa dam, state of Goiás, Brazil. I. Frequency and climatic factors. Cad Saude Publica 2004; 20:109-118.

8. Roberts DR, Hsi BP. An index of species abundance for use with mosquito surveillance data. Env Entomology 1979; 8:1007-1013.
9. Haddow AJ. Studies on the biting-habits and medical importance of eats African mosquitoes in the genus Aedes. I. Subgenera Aedimorphus, Bankisinella and Dunnius. Bull Ent Res 1960; 50:759-779.

10. Hammer O, Harper DAT, Ryan PD. Past: paleontological statistics software package for education and data analysis. Paleontologia Electronica 2001; 4: art 4.

11. Paula MB, Gomes AC, Natal D, Duarte AMRC, Mucci LF. Effects of Artificial Flooding for Hydroelectric Development on the Population of Mansonia humeralis (Diptera: Culicidae) in the Paraná River, São Paulo, Brazil. J Trop Med 2012; ID:598789.

12. Forattini OP. Culicidologia médica. Vol 2. São Paulo: EDUSP Editora da Universidade de São Paulo; 2002.

13. Guimarães AE, Mello RP, Lopes CM, Gentile C. Ecology of mosquitoes (Diptera: Culicidae) in areas of Serra do Mar State Park, state of São Paulo, Brazil. I. Monthly frequency and climatic factors. Mem Inst Oswaldo Cruz 2000; 95:1-16.

14. Guimarães AE, Gentile C, Lopes CM, Sant'anna A. Ecologia de mosquitos em áreas do Parque Nacional da Serra da Bocaina. II. Frequência mensal e fatores climáticos. Rev Saude Publica 2001; 35:392-399.

15. Silva JS, Pacheco JB, Alencar J, Guimarães AE. Biodiversity and influence of climatic factors on mosquitoes (Diptera: Culicidae) around the Peixe Angical hydroelectric scheme in the state of Tocantins, Brazil. Mem Inst Oswaldo Cruz 2010; 105:155-162.

16. Zeilhofer P, Santos ES, Ribeiro ALM, D'Junco RM, Santos MAD. Habitat suitability mapping of Anofeles darlingi in the surroundings of the Manso hydropower plant reservoir, Mato Grosso, Central Brazil. Int J Health Geogr 2007; 6:1-24. 